\title{
A new species of Pardosa (Araneae: Lycosidae) from Sadogashima Is., Japan
}

\author{
Akio Tanikawa ${ }^{1}$, Nisikawa Usio $^{2}$, Atsushi Ohwaki ${ }^{2}$, Chihiro Endo ${ }^{2}$ \& Tadashi Miyashita $^{1}$ \\ ${ }^{1}$ Laboratory of Biodiversity Science, School of Agriculture and Life Sciences, \\ The University of Tokyo, 1-1-1, Yayoi, Bunkyo-ku, Tokyo, 113-8657 Japan \\ E-mail:dp7a-tnkw@j.asahi-net.or.jp \\ ${ }^{2}$ Center for Toki and Ecological Restoration, Niigata University, \\ 1101-1 Niibokatagami, Sado, 952-0103 Japan
}

\begin{abstract}
A new species, Pardosa albomarginata, is described from Sadogashima Is., Niigata Prefecture, Japan.
\end{abstract}

Key words - Pardosa albomarginata, Niigata, paddy field

\section{Introduction}

Pardosa is well studied genus in Japan (Tanaka 1993a-d, 1998, 2005), and 28 species have been recorded from the country to date. However, there have been few studies on the attached islands other than Ryukyu Isls. Recently, we obtained many specimens of undescribed species of the genus from paddy fields on Sadogashima Island, the largest island near northern coast of Honshu, Japan. It is described as a new species in this paper.

Specimens were preserved in $75 \%$ ethanol, and their morphological features were observed under stereoscopic microscope M3Z (Wild Heerbrugg AG, Heerbrugg, Switzerland). The photos of male palp and epigyne were taken by digital camera EOS Kiss X7 (Canon Inc., Tokyo, Japan) connected to the stereoscopic microscope. The type series designated in this study are deposited in the collection of the Department of Zoology, National Museum of Nature and Science, Tokyo (NSMT).

This study was funded by the Ecological Restoration Program (Sponsored Program by Sado City) at Center for Toki and Ecological Restoration (CTER), Niigata University. We thank the members of CTER for facilitating the study.

Pardosa albomarginata $\mathrm{n}$. sp.

[Japanese name: Herijiro-komorigumo]

(Figs. 1-5)

Type series. All the specimens were collected by A. Ohwaki \& C. Endo unless noted otherwise. Holotype. $\delta^{7}, 9-$ VI-2011, western part of Kuninaka Plain, Sadogashima Is., Niigata Pref., Japan (NSMT-Ar 12392). Paratypes. 1우3 $0^{\top}$, 8-VI-2011, 2우, 9-VI-2011, 1우, 5-VII-2011, the same locality as the holotype (NSMT-Ar 12393-12399). 1우수, 25-V2013, Sawane, same island (N38.00615 E138.26013), Y. G. Baba \& A. Tanikawa leg. (NSMT-Ar 12400-12401).
Other specimens examined. 31우11 the same locality as the holotype in June or July, 2011.

Etymology. The specific name is derived from the markings on the carapace.

Diagnosis. The general appearance of $P$. albomarginata (Figs. 1, 2) resembles P. plumipes (Thorell 1875) (see Chikuni 1989, p. 114, fig. 27), but the two can be easily distinguished by the shape of the epigyne and male palp. The septum of epigyne is much larger in $P$. plumipes (Tanaka 1993, fig. 9) compared to that in P. albomarginata (Fig. 3). The tegular apophysis of the male palp is more robust and larger in P. plumipes (see Tanaka 1993, fig. 11) compared to that in $P$. albomarginata (Fig. 5). The shape of the epigyne and male palp of $P$. albomarginata closely resemble those of $P$. isago Tanaka 1977, although the general appearances of these species are quite different from each other. The carapace of $P$. albomarginata has three white bands in the middle and on both sides (Figs. 1 and 2), while in $P$. isago the carapace appears almost uniformly dark grey in life (see Chikuni 1989, p. 115, fig. 32) and these bands remain indistinct in alcohol. The male 1st tarsus and metatarsus of $P$. isago also has many long hairs (Tanaka 1993), whereas $P$. albomarginata does not have this feature (Fig. 2).

Description. Measurements. $0^{x /} / 9$, measurements in parentheses indicate the range among type series. Body $7.60(6.80-7.60) / 9.50(7.60-11.23)$ long. Carapace 3.84 $(3.44-3.84) / 4.44(3.96-4.69)$ long; $3.00(2.56-3.00) / 3.25$ (3.03-3.50) wide. Length of legs [tarsus + metatarsus + tibia + patella + femur $=$ total]: $\mathrm{I}, \quad 1.76+2.28+2.20+1.32$ $+2.80=10.36 / 1.88+2.50+2.56+1.64+3.24=11.82 ; \quad$ II, $1.68+2.28+2.04+1.32+2.76=10.08 / 1.88+2.40+2.36+$ $1.60+3.20=11.44 ;$ III, $1.60+2.60+2.00+1.24+2.68=$ $10.12 / 1.88+3.04+2.32+1.52+3.08=11.84 ; \quad I V, 2.16+$ $4.08+2.84+1.40+3.48=13.96 / 2.12+4.24+3.20+1.48+$ $3.64=14.68$. Abdomen $3.60(2.92-3.60) / 4.69(3.60-5.94)$ long; $2.12(2.00-2.36) / 3.13(2.44-3.94)$ wide. 


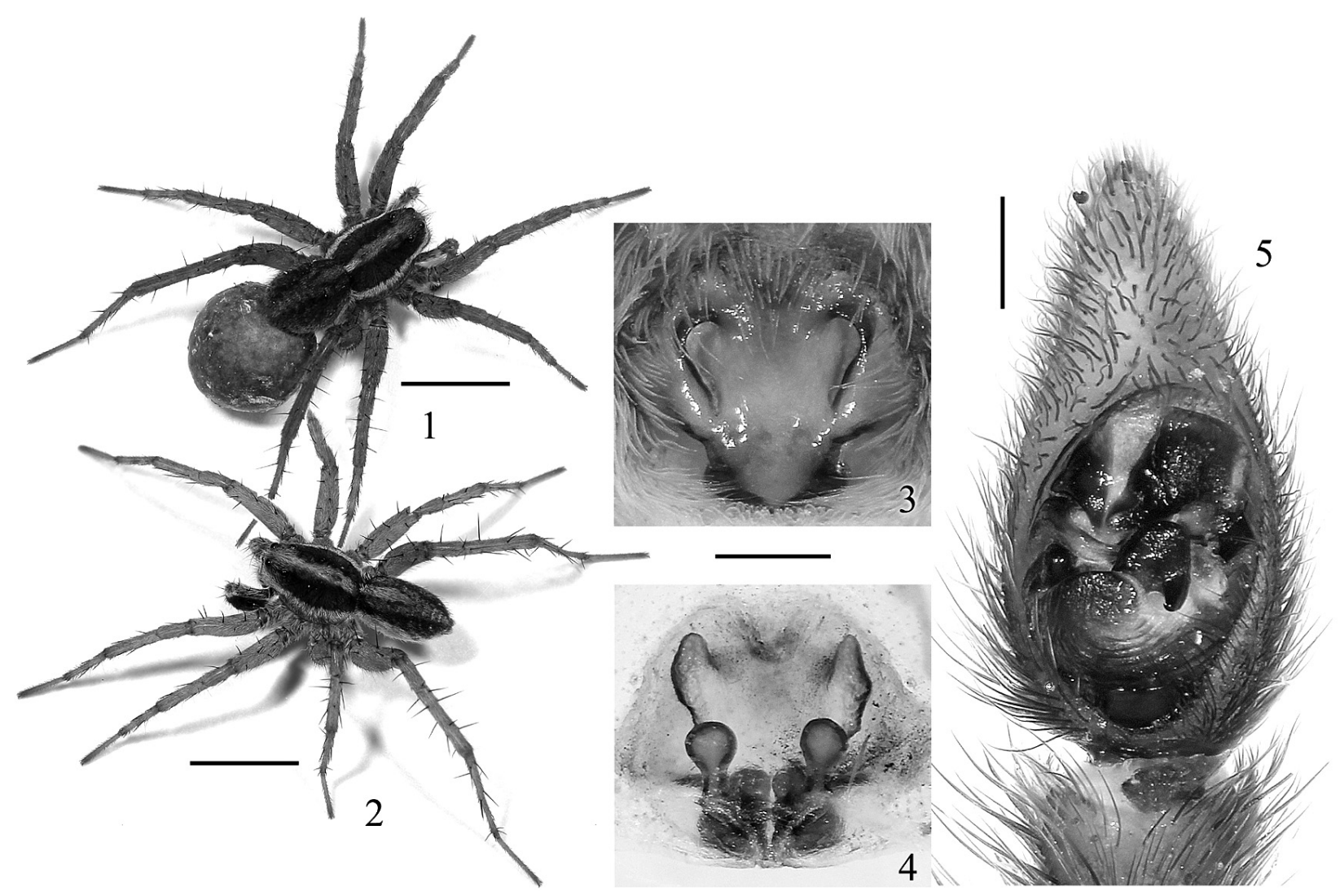

Figs. 1-5. Pardosa albomarginata n. sp. 1, female with egg sac (paratype, NSMT-Ar 12400); 2, male (paratype, NSMT-Ar 12401); 3, epigyne, ventral view (paratype, NSMT-Ar 12397); 4, same, dorsal view; 5, male palp, ventral view (holotype, NSMT-Ar 12392). Scales $=5 \mathrm{~mm}(1-2) ; 0.25 \mathrm{~mm}\left(3^{-5}\right)$.

Female and male. Carapace longer than wide [length divided by width $1.28(1.28-1.34) / 1.37(1.29-1.42)]$. Median ocular area wider than long [length divided by width 0.58 $(0.57-0.58) / 0.57\left(0.56^{-0.59)}\right]$; wider in front than behind [anterior width divided by posterior width $1.28\left(1.28^{-}\right.$ $1.31) / 1.33(1.32-1.35)]$. Labium wider than long [length divided by width $0.65 \quad(0.59-0.74) / 0.84 \quad(0.60-0.84)]$. Sternum slightly longer than wide [length divided by width $1.12\left(1.12^{-1.20) / 1.12(1.08-1.17)] . ~ L e n g t h ~ o f ~ l e g ~ I ~ d i v i d e d ~}\right.$ by length of carapace $2.70(2.64-2.84) / 2.66(2.29-2.66)$. Male palp (Fig. 5): tegular apophysis small, with small process projecting basally. Abdomen longer than wide [length divided by width $1.70\left(1.46^{-1.70) / 1.50 ~(1.48-1.57) . ~}\right.$ Epigyne (Figs. 3-4): width of septum between pockets wider than near base.

Distribution. Japan (Sadogashima Is., Niigata Pref.).

Notes. The epigyne and male palp of $P$. albomarginata resemble the figures of $P$. lyrifera Schenkel 1936 made by several authors (Yu \& Song 1988, figs. 1-2; Chen \& Zhang 1991, figs. 206.1-4; Kim \& Yoo 1997, figs. 9, 22-23, 4041; Yin et al. 1997, fig. 105; Kim 1999, p.1, fig. 7-9; Song et al. 1999, figs. 195Q, 196A; Hu 2001, figs. 94.1-4; Song et al. 2001, figs. 156A-D), but these figures do not agree with the original one described by Schenkel (1936, fig. 77). The epigyne of $P$. lyrifera appears to have a large septum, but all of the figures made by the above authors do not have such a large septum. Thus, these identifications seem to be wrong, and it is likely that these specimens seem to be conspecific with $P$. albomarginata or another species not described yet.

\section{References}

Chen, Z. F. \& Zhang, Z. H. 1991. Fauna of Zhejiang: Araneida. Zhejiang Sci. Technol. Publ. House, 356 pp.

Chikuni, Y. 1989. Pictorial Encyclopedia of Spiders in Japan. Kaiseisha, Tokyo, 310 pp. (In Japanese)

Guo, J. F. 1984. Spiders of Shaanxi agricultural fields. Shaanxi Sci. Technol. Publ. House, 227 pp.

Hu, J. L. 2001. Spiders in Qinghai-Tibet Plateau of China. Henan Sci. Technol. Publ. House, 658 pp.

Kim, J. P. 1999. Taxonomic study of P. lyrifera and $P$. isago on the genus Pardosa (Araneae: Lycosidae) from Korea. Korean Arachnol., 15: 1-6.

Kim, J. P. \& Yoo, J. S. 1997. Korean spiders of the genus Pardosa C. L. Koch, 1848 (Araneae: Lycosidae). Korean Arachnol., 13: 31-45.

Schenkel, E. 1936. Schwedisch-chinesische wissenschaftliche Expedition nach den nordwestlichen Provinzen Chinas, unter Leitung von Dr. Sven Hedin und Prof. S. Ping-chang. Araneae gesammelt vom schwedischen Artz der Exped. Ark. Zool., 29: 1314.

Song, D. X., Zhu, M. S. \& Chen, J. 1999. The Spiders of China. Hebei Sci. Technol. Publ. House, Shijiazhuang, 640 pp.

Song, D. X., Zhu, M. S. \& Chen, J. 2001. The Fauna of Hebei, China: 
Araneae. Hebei Sci. Technol. Publ. House, 510 pp.

Tanaka, H. 1977. Two new species of the genus Pardosa C. Koch from Japan (Araneae: Lycosidae). Acta Aarachnol., 27 (Spec. No.): 51-59.

Tanaka, H. 1993a. Lycosid spiders of Japan IX. The genus Pardosa C. L. Koch - amentata - group. Sonoda Women's College Studies, 27: $261-318$.

Tanaka, H. 1993b. Lycosid spiders of Japan X. The genus Pardosa C. L. Koch - monticola - group. Bull. Biogeogr. Soc. Japan, 48: 916.

Tanaka, H. 1993c. Lycosid spiders of Japan XI. The genus Pardosa C. L. Koch - paludicola - group. Acta Arachnol., 42: 159-171.

Tanaka, H. 1993d. Lycosid spiders of Japan XII. The genus Pardosa
C. L. Koch - pullata - group and P. lyrivulva. Acta Arachnol, 42: $173-179$.

Tanaka, H. 1998. A new species of the genus Pardosa (Araneae: Lycosidae) from Japan. Acta Arachnol., 47: 101-103.

Tanaka, H. 2005. A new species of the genus Pardosa (Araneae: Lycosidae) from Hokkaido, Japan. Biogeography, 7: 7-9.

Yin, C. M., Wang, J. F., Zhu, M. S., Xie, L. P., Peng, X. J. \& Bao, Y. M. 1997. Fauna Sinica: Arachnida: Araneae: Araneidae. Science Press, Beijing, 460 pp.

Yu, L. M. \& Song, D. X. 1988. A revision of the Chinese spiders of the family Lycosidae (Araneae). Sinozool., 6: 113-121.

Received August 13, 2013 / Accepted October 3, 2013 